\title{
Hydrogeology of the Lloyd Aquifer on Long Island, New York-A Brief Summary of USGS Investigations
}

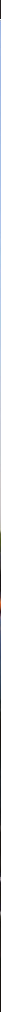

The Lloyd aquifer contains about 9 percent of Long Island's potable water and has been a source of public-water supply

1 since the early part of the $20^{\text {th }}$ century. Many studies during the $20^{\text {th }}$ century have provided information on this confined aquifer and helped refine its representation in ground-water flow models.

The Lloyd is the lowermost aquifer on Long Island and has the lowest transmissivity (1,500 to 19,000 feet squared per day). The Lloyd receives 3.1 percent of Long Island's total recharge through a narrow corridor along the island's ground-water divide. Nearly all pumping from the Lloyd aquifer has been in the western part of Long Island; the maximum annual withdrawal was about 6.4 billion gallons in Nassau County in 1971. Excessive pumpage has led to saltwater intrusion in the Lloyd aquifer in coastal areas. 


\section{Introduction}

The four counties of Long Island (fig. 1) are underlain by a wedge-shaped sequence of unconsolidated deposits of Late Cretaceous and Pleistocene age that lie unconformably on crystalline bedrock (fig. 2). A saprolitic (weathered bedrock) zone 20 to $100 \mathrm{ft}$ thick overlies the bedrock in most areas. The sequence of unconsolidated deposits thickens to the south and southeast by about 65 to 100 feet per mile and contains Long Island's fresh ground water.

Long Island's ground-water system consists of four main aquifers-the upper glacial, the Jameco, the Magothy, and the Lloyd. The Lloyd aquifer underlies nearly all of Long Island (fig. 3), but pumpage from the Lloyd has been limited to the northern and southern coastal areas of the island by the New York State Department of Environmental Conservation since about 1955 (Garber, 1986). Coastal areas are exempt where the Lloyd is the only source of potable water. The former Jamaica Water Supply Corporation (now owned by New York City) is a noted exception withdrawing as much as 6 million gallons per day (Mgal/d) since the mid-1930s from the Lloyd in central Queens County.

This paper: (1) provides a brief history of U.S. Geological Survey (USGS) studies that provided significant data on the Lloyd, (2) summarizes the hydraulic characteristics of the Lloyd as reported in those studies, and (3) describes present-day monitoring of the Lloyd by the USGS.

\section{Previous Studies}

The earliest comprehensive study of Long Island's groundwater resources was done by Veatch and others (1906), who were the first to name a stratigraphic deposit from Lloyd Neck as the "Lloyd sand." Suter (1937) estimated the potential ground water yield of the four aquifers, including the Lloyd sand, in each county. Suter and others (1949) mapped Long Island's geologic units, at which time they named the Lloyd sand member and grouped it with the Raritan Formation. Cohen and others (1968) were the first to use the name Lloyd aquifer for the Lloyd Sand Member. McClymonds and Franke (1972) estimated hydraulic properties of the Lloyd and other aquifers on Long Island. Franke and Cohen (1972) estimated regional rates of ground-water movement and the age of ground water in the upper glacial, Magothy, and Lloyd aquifers on Long Island. Kimmel (1973) mapped the potentiometric surface of the Lloyd throughout Long Island and the changes in its altitude between 1900 and 1970. Sirkin $(1974,1986)$ used pollen data to revise the stratigraphy of the Cretaceous age sediments on Long Island and correlate them with stratigraphic units off of Long Island. Rich and others (1975) and Donaldson and Koszalka (1983) mapped the potentiometric surface of the Lloyd aquifer on Long Island in 1975 and 1979, respectively. Garber (1986) provided a compilation of previous hydrogeologic investigations of the Lloyd aquifer. Doriski $(1986,1987)$ mapped the watertable and potentiometric-surface altitudes of the upper glacial,

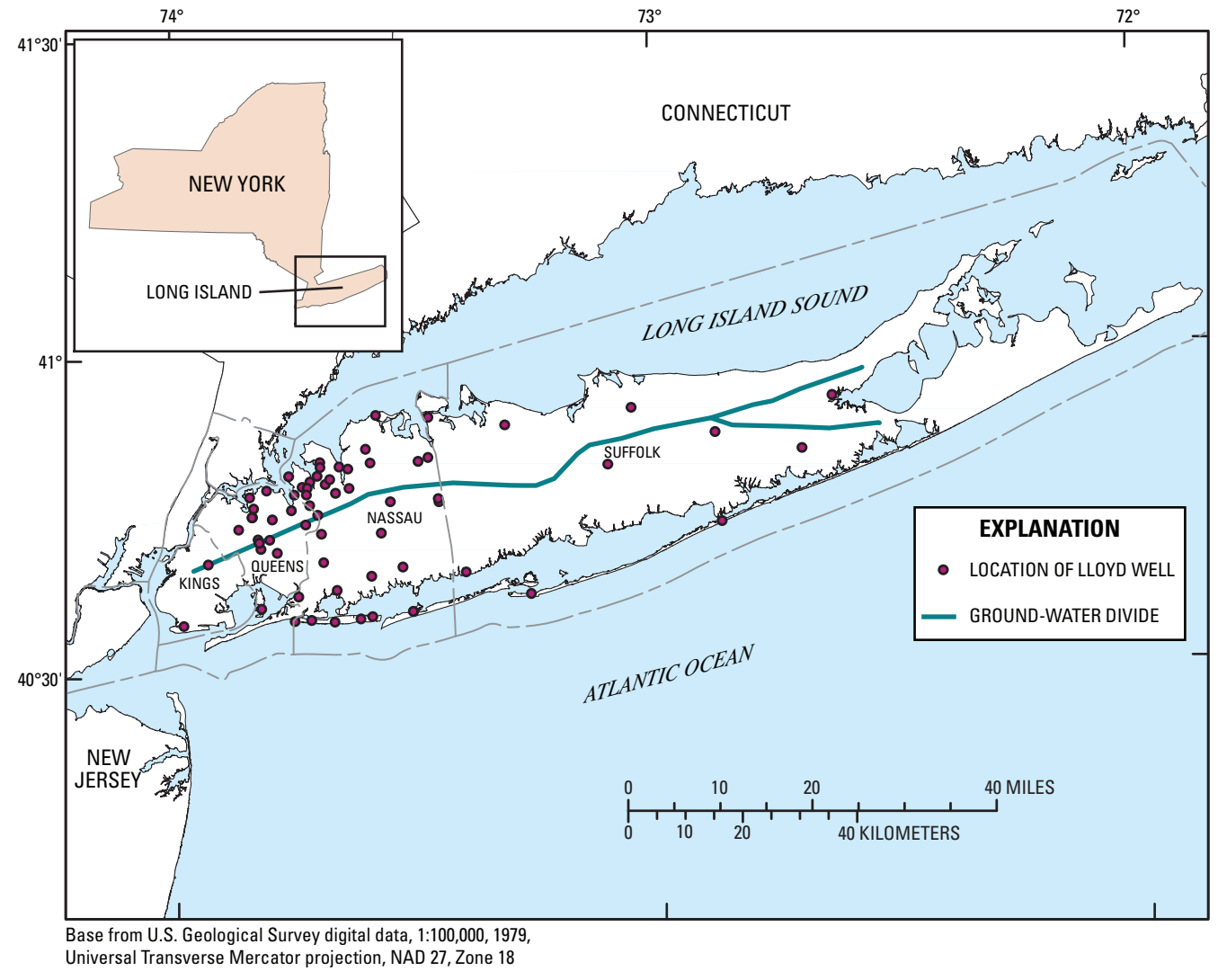

Figure 1. Approximate location of ground-water divide, Kings, Queens, Nassau, and Suffolk Counties on Long Island, N.Y. 


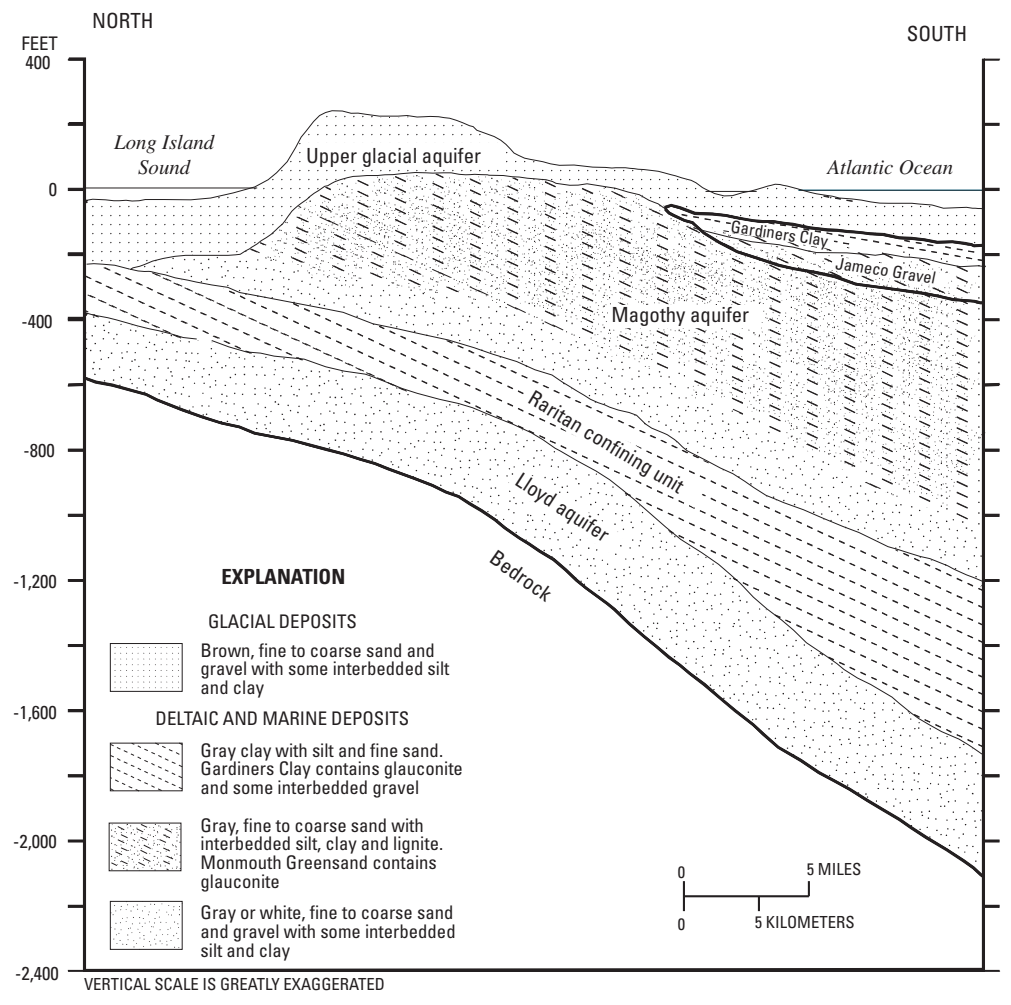

Figure 2. Cross section showing lithology of major hydrogeologic units along a generalized north-south section through the ground-water system of Long Island, N.Y. (Section represents an area near the Nassau-Suffolk County border.) (Modified from McClymonds and Franke, 1972, fig. 3)

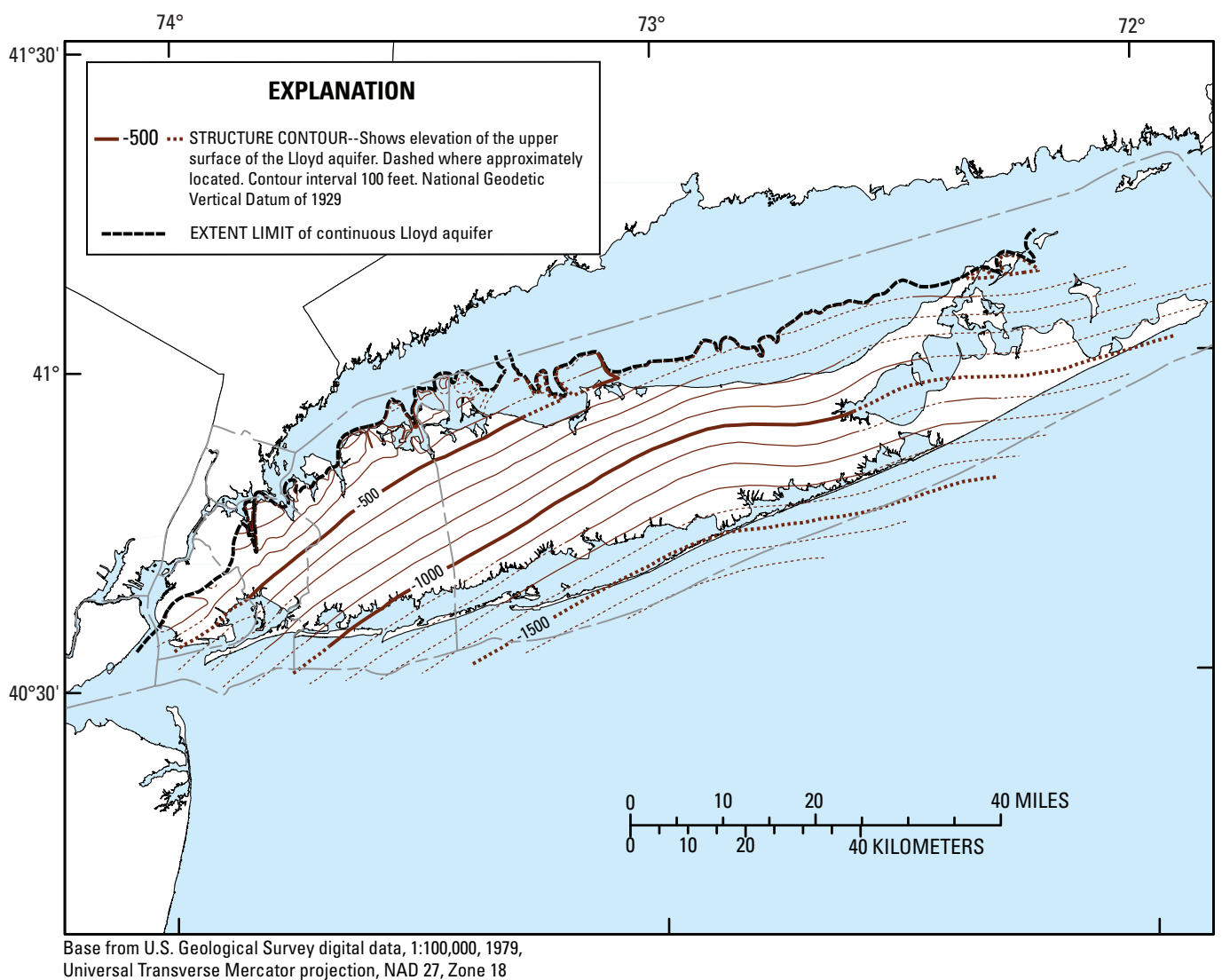

Figure 3. Extent and elevation of the upper surface of the Lloyd aquifer on Long Island, N.Y. (Modified from Smolensky and others, 1989) 
Magothy, and Lloyd aquifers on Long Island in 1983 and 1984, respectively. Soren and Simmons (1987) mapped the thickness of each aquifer and confining unit below the upper glacial aquifer throughout Long Island. Smolensky and others (1989) incorporated data from previous studies to map the hydrogeologic framework of Long Island. Buxton and others (1991) and Buxton and Smolensky (1999) used a threedimensional numerical model and particle-tracking analysis of Long Island's ground-water flow system to estimate the rates of recharge to the Magothy and Lloyd aquifers and to delineate their recharge areas. Buxton and Modica (1992) simulated patterns and rates of ground-water flow to analyze recharge along a cross-section at the Nassau-Suffolk County border. Busciolano and others (1998) mapped the water-table and potentiometric-surface altitudes of the upper glacial, Magothy, and Lloyd aquifers on Long Island.

Kilburn (1982), Buxton and others (1981), Snavely and Williams (1984), and Chu and others (1997) reported pumpage from the Lloyd in western Long Island. They, however, did not report pumpage values from the Lloyd aquifer in Suffolk County, but included pumpage from the Lloyd in Nassau County, which has the largest consumptive use of water from the Lloyd. Buxton and others (1981) and Chu and others (1997) reported pumpage from the Lloyd aquifer in Kings, Queens and Nassau Counties.

Perlmutter and Geraghty (1963) studied the geology and ground-water conditions in southern Nassau and southeastern Queens and demonstrated that the Lloyd aquifer is hydraulically separated from the overlying units and contains freshwater.

Many local studies that provided information on the hydrogeologic framework of Long Island's ground-water system are not mentioned here because their focus was beyond the scope of this report. A few are mentioned further on, however, that are focused on quantifying pumpage from the Lloyd and mapping and modeling saltwater intrusion.

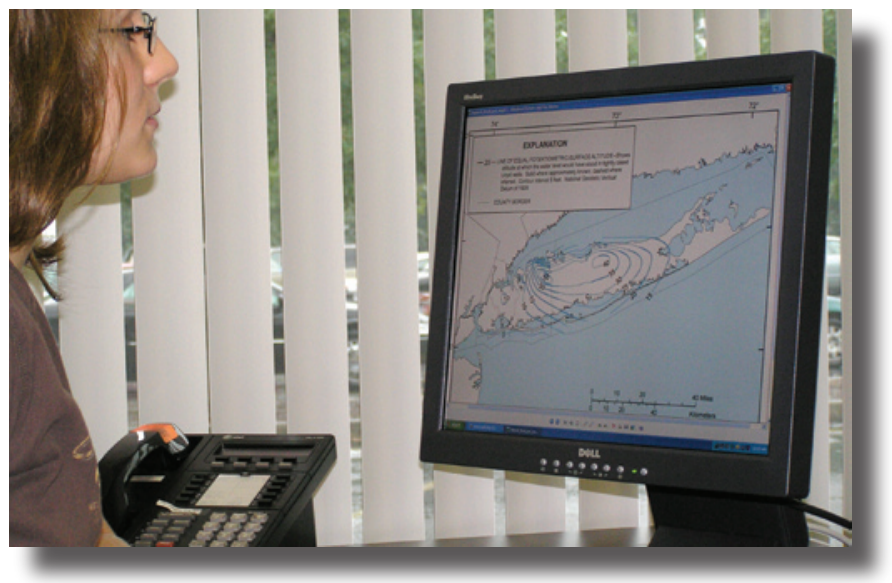

A Geographic Information System links spatially referenced databases, and facilitates refinement of the regional hydrogeologic framework and analysis of changes over time to Lloyd aquifer potentiometric-surface altitude and water-quality conditions.

\section{Hydrogeology}

The Lloyd aquifer (Lloyd Sand Member of the Raritan Formation), is the oldest of the Cretaceous age formations on Long Island. It extends from central Kings, northwestern
Queens and Nassau, and northeastern Suffolk Counties to the east and south (fig. 3). It lies unconformably upon the bedrock surface and is bounded conformably above by the Raritan confining unit (unnamed clay member of the Raritan Formation), or Raritan clay (fig. 2). The Raritan clay has a very low vertical hydraulic conductivity of .001 feet per day ( $\mathrm{ft} / \mathrm{d}$ ) and is areally extensive, making the Lloyd aquifer the only fully confined aquifer on Long Island. The Lloyd thickens to the southeast on the western portion of Long Island and to the south on the eastern portion. The thickness of the Lloyd aquifer varies from zero in northern Kings, northwest Queens and Nassau, and northeast Suffolk Counties - to over $500 \mathrm{ft}$ in south central Suffolk County.

Lloyd aquifer deposits generally consist of fine to coarse, quartz-rich sand and gravel, commonly within a clayey matrix (see photos, p. 5). The coarse sand particles are subangular to rounded, and thin lenses of clay are common, as are lenses of fine sandy clay and clayey sand. Some clay lenses are as thick as $40 \mathrm{ft}$ and may extend more than one mile locally. However, these clay units do not seem to affect the hydraulic interconnectivity of the Lloyd. Lloyd deposits are generally clear or white, but may also be yellow or gray.

The clayey matrix of the Lloyd aquifer gives it moderate to low permeability. The average horizontal hydraulic conductivity ranges from $40 \mathrm{ft} / \mathrm{d}$ (McClymonds and Franke, 1972) to $67 \mathrm{ft} / \mathrm{d}$ (Soren, 1971), and its horizontal to vertical anisotropy is about 10:1 (Smolensky and others, 1989). The average transmissivity of the Lloyd is about one-third that of the Magothy aquifer, and ranges from about 1,500 to $19,000 \mathrm{ft}^{2} / \mathrm{d}$ (Garber, 1986). Average transmissivity varies locally from about 4,700 $\mathrm{ft}^{2} / \mathrm{d}$ in Kings County, 8,000 $\mathrm{ft}^{2} / \mathrm{d}$ in Queens County, $12,000 \mathrm{ft}^{2} / \mathrm{d}$ in northern Nassau County, 16,000 $\mathrm{ft}^{2} / \mathrm{d}$ in southern Nassau County, and 10,000 to $12,000 \mathrm{ft}^{2} / \mathrm{d}$ in Suffolk County (McClymonds and Franke, 1972).

The general configuration of the potentiometric-surface altitude of the Lloyd aquifer (fig. 4) is similar to that of the upper glacial and Magothy aquifers. It gradually rises from the western part of Long Island to form an east-west-trending mound in eastern Nassau County that continues eastward into central Suffolk County and then generally declines toward the eastern end of Long Island.

The quality of water in the Lloyd aquifer is generally good; although high iron content and salinity have been noted locally. Several local studies mapped the extent of saltwater intrusion in several coastal areas of Long Island. Stumm (2001), and Stumm and others $(2002,2004)$ delineated areas of saltwater intrusion in the Lloyd aquifer on the north shore of Nassau County. Misut and others (2002) used a three-dimensional finite-element model to simulate saltwater intrusion in the four major aquifers in Kings, Queens, and western Nassau Counties. Terracciano (1997) updated previous studies of saltwater intrusion in southeastern Queens and southwestern Nassau Counties. Soren (1971) mapped the northern extent of saltwater intrusion into the Lloyd aquifer in Queens County. Lusczynski and Swarzenski (1966) studied the saltwater intrusion and mapped landward extent of saltwater in the Lloyd and the other aquifers in southern Nassau and southeastern Queens Counties; they also estimated the rates of landward movement of saltwater, by depth and area. 

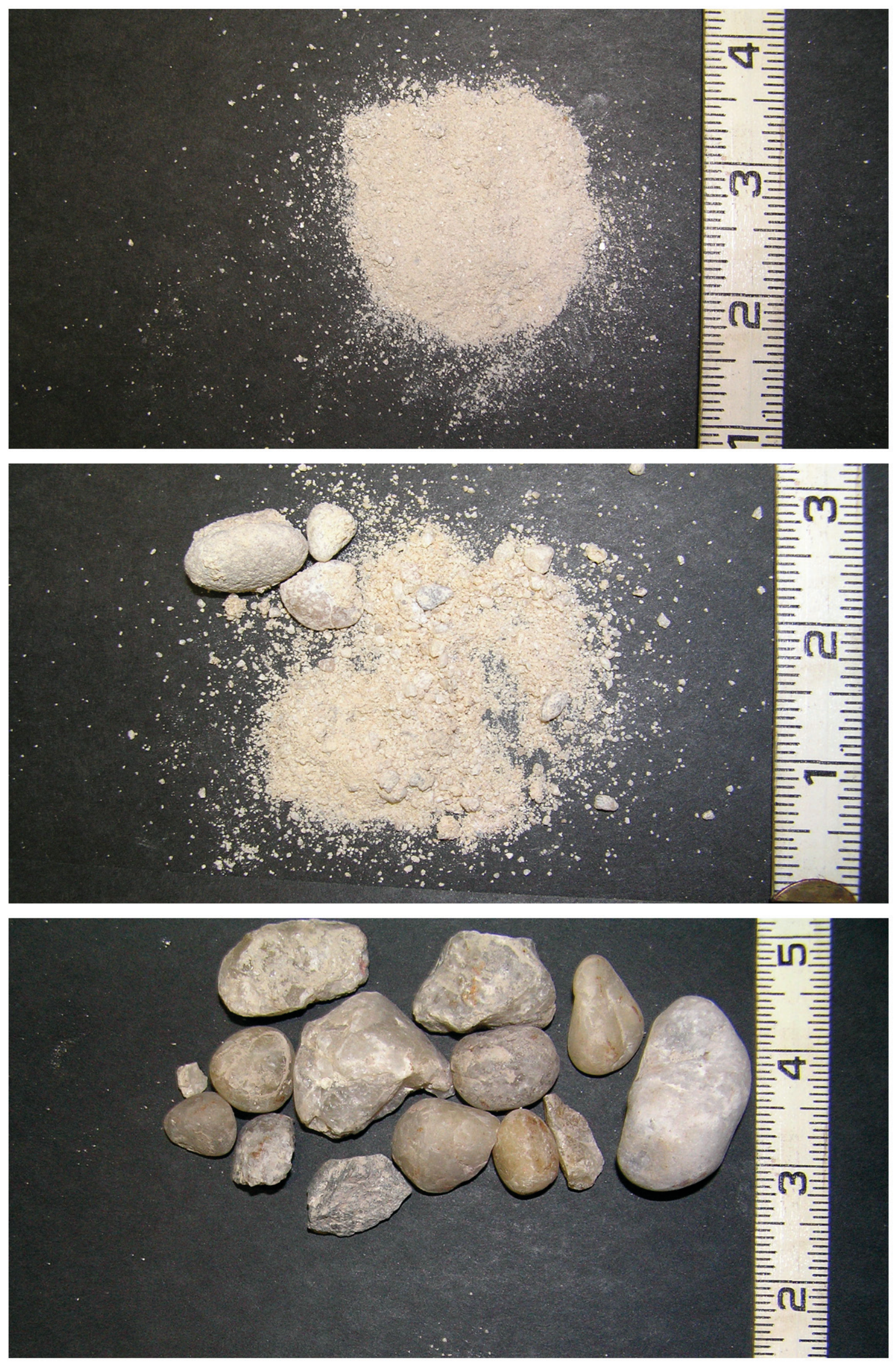

Photographs of Lloyd core samples collected from northern Nassau County, N.Y., show the upward fining sequence of the Lloyd aquifer. (Units are in inches.) 


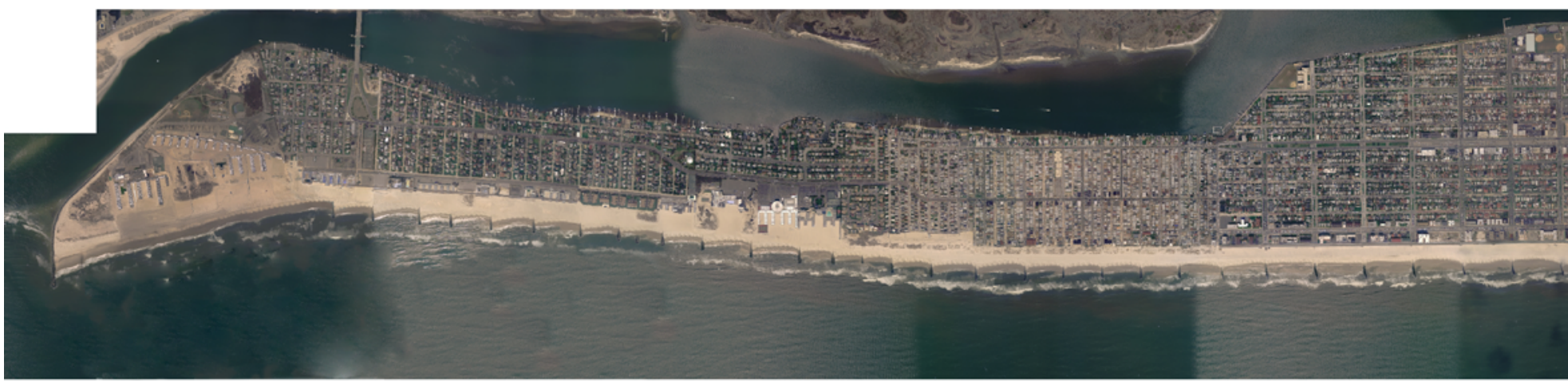

The Lloyd aquifer is the sole source of public water-supply for Long Beach Island, Nassau County, N.Y. (Composite aerial photo of Long Beach from New York State Statewide D

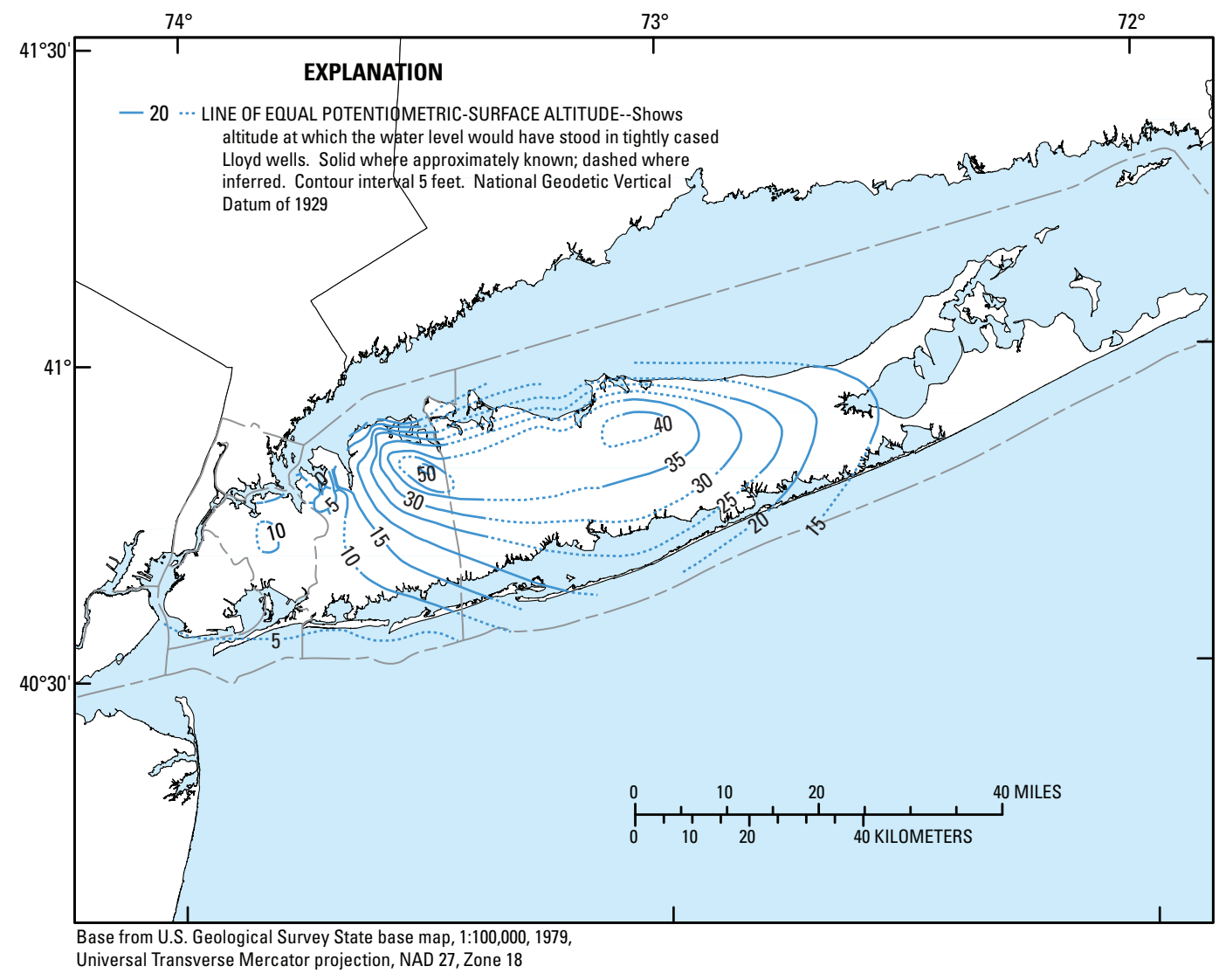

Figure 4. Potentiometric-surface altitude of the Lloyd aquifer in March-April 1997 on Long Island, N.Y. (Modified from Busciolano and others, 1998 ) 
Open-hole borehole-geophysical logging at a 1,700 foot-deep Lloyd well on Jones Beach Island, Nassau County, N.Y.
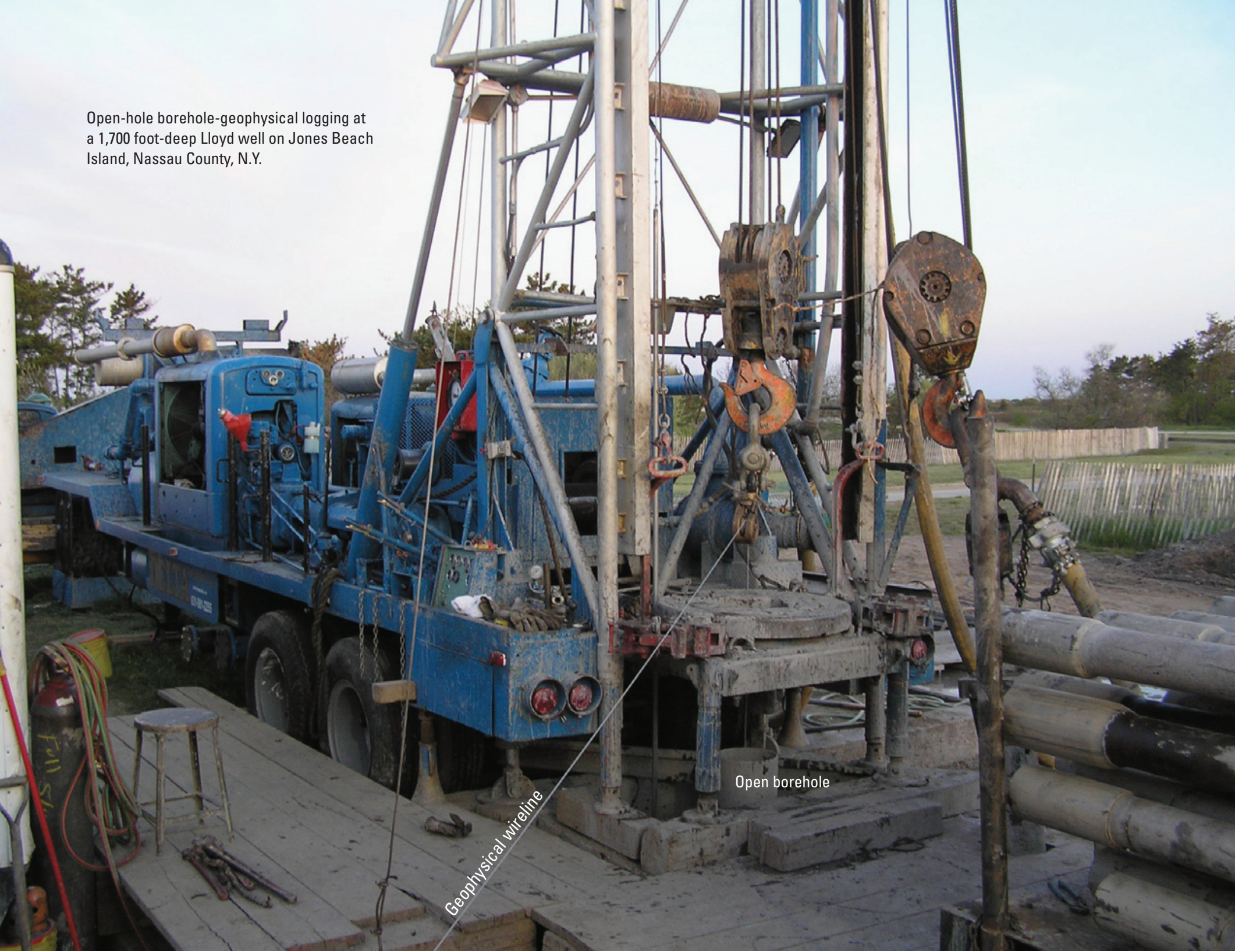

\section{Recharge}

The Raritan clay protects the Lloyd aquifer from contamination from the overlying aquifers, but also inhibits recharge to the Lloyd. The Lloyd aquifer has been estimated to contain about 9 percent of Long Island's freshwater (Garber, 1985), but receives only 3.1 percent of the recharge that enters the Long Island aquifer system (Buxton and others, 1991; Buxton and Modica, 1992). The Lloyd aquifer receives this recharge through a corridor generally less than 0.5 miles wide that lies approximately along the ground-water divide (fig. 1). Traveltime from the water table to the top of the Lloyd aquifer has been estimated to be on the order of several hundred years (Buxton and others, 1991). The age of water in the Lloyd aquifer is oldest at the southern coast of Long Island, where it is more than 8,000 years old; and is more than 2,000 years old at the northern coast (Buxton and Modica, 1992). This difference in age is attributed mainly to the proximity of the recharge area to the north shore.

\section{Present-Day Monitoring}

The Long Island branch of the USGS New York Water Science Center, located in Coram, New York, (in 2006) monitors water levels at about 63 Lloyd wells on Long Island; two in Kings, six in Queens, 17 in Nassau, and five in Suffolk Counties. Island-wide, nine of the 63 wells are continuous record sites, 30 are measured monthly, and 45 are measured annually. The number of wells in the network varies annually as wells are destroyed, replaced, or access to wells changes.

Water-quality samples are collected at about three Lloyd wells annually on Long Island. Borehole geophysical logs are collected to delineate geology at all new Lloyd wells that are drilled, and induction logs are collected to delineate and monitor the extent of saltwater intrusion. Borehole-geophysical logs (including gamma, electrical resistivity, and electromagneticinduction (EM) logs) are collected at about four Lloyd wells annually. 

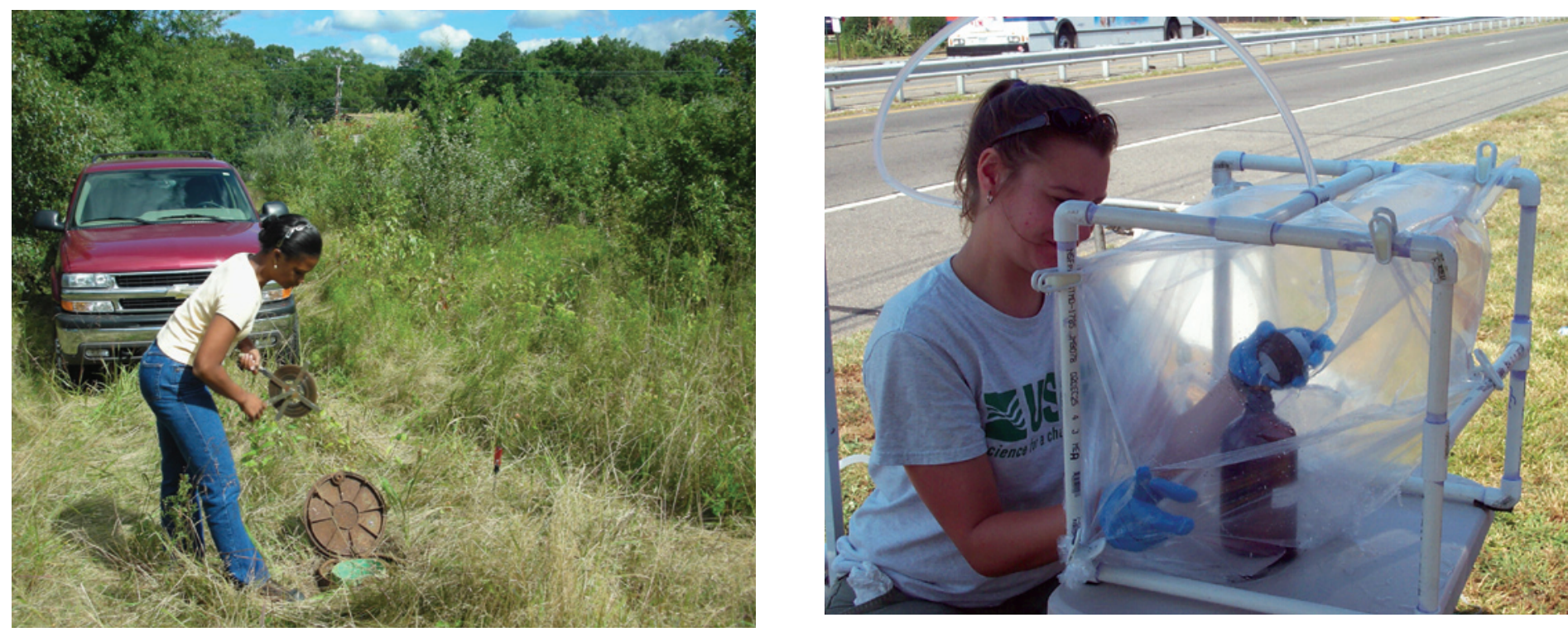

The USGS measures water levels (above left) at about 63 Lloyd wells, and collects water-quality samples (above right) from about three Lloyd wells on Long Island, N.Y. annually.

\section{Summary}

The Lloyd aquifer, the deepest of the four main aquifers on Long Island, has supplied as much as 1.1 Bgal of public-supply water per year from Kings County, 3 Bgal from central Queens County, and 6.4 Bgal from shoreline communities in Nassau County. Many hydrogeologic studies since 1903 have provided the data needed to describe the hydrogeologic framework of the Lloyd. Several local studies have made significant contributions to the refinement of the regional hydrogeologic framework.

The Lloyd aquifer has the lowest average horizontal hydraulic conductivity and transmissivity of the four main aquifers on Long Island. Average horizontal hydraulic conductivity ranges from 40 to $67 \mathrm{ft} / \mathrm{d}$, and transmissivity ranges from 1,500 to $19,000 \mathrm{ft}^{2} / \mathrm{d}$. Average transmissivity varies locally; from about 4,700 $\mathrm{ft}^{2} / \mathrm{d}$ in Kings County, to $8,000 \mathrm{ft}^{2} / \mathrm{d}$ in Queens County, 12,000 ft $2 / \mathrm{d}$ in northern Nassau County, $16,000 \mathrm{ft}^{2} / \mathrm{d}$ in southern Nassau County, and 10,000 to 12,000 $\mathrm{ft}^{2} / \mathrm{d}$ in Suffolk County. Several saltwater wedges in the Lloyd that were induced by over-pumping on western Long Island have been mapped in local studies. Pumpage from the Lloyd in Kings County ceased in 1946 but continues today in Queens and Nassau Counties along with a handful of sole source water supply wells on the barrier beaches of Suffolk County.

Only 3.1 percent of recharge on Long Island enters the Lloyd aquifer through a corridor that is generally less than 0.5 mi. wide, and located approximately along the ground-water divide. Traveltime from the water table to the top of the Lloyd aquifer is several hundred years. The age of water in the Lloyd aquifer ranges from 2,000 years at the northern shore to 8,000 years at the southern shore.

The USGS New York Water Science office in Coram, New York, (in 2006) monitors water levels at a network of about 63
Lloyd wells on Long Island, and samples about three Lloyd wells annually for water quality. Gamma and electric logs are collected to help delineate geology at all new Lloyd wells that are drilled, and EM logs are collected to delineate and monitor saltwater intrusion.

By Anthony Chu, U.S. Geological Survey, Coram, NY

\section{References}

Busciolano, Ronald, Monti, Jack, Jr., and Chu, Anthony, 1998, Water-table and potentiometric-surface altitudes of the upper glacial, Magothy, and Lloyd aquifers on Long Island, New York, in March-April, 1997, with a summary of hydrogeologic conditions: U.S. Geological Survey WaterResources Investigations Report 98-4019, 17 p., 6 pls.

Buxton, H.T. and Smolensky, D.A., 1999, Simulation of the effects of development of the ground-water flow system of Long Island, New York: U.S. Geological Survey WaterResources Investigations Report 98-4069, 57 p.

Buxton, H.T. and Modica, Edward, 1992, Patterns and rates of ground-water flow on Long Island, New York: Ground Water, v. 30 , no. 6, p. 857-866.

Buxton, H.T., Reilly, T.E., Pollock, D.W., and Smolensky, D.A., 1991, Particle tracking analysis of recharge areas on Long Island, New York: Ground Water, v. 29, no. 1, p. 63-71. 
Buxton, H.T., Smolensky, D.A., and Shernoff, P.K., 1989, Hydrogeologic correlations for selected wells on Long Island, New York-A data base with retrieval program: U.S. Geological Survey Water-Resources Investigations Report 86-4318, 107 p.

Buxton, H.T., Soren, Julian, Posner, Alex, and Shernoff, P.K., 1981, Reconnaissance of the ground-water resources of Kings and Queens Counties, New York: U.S. Geological Survey Open-File Report 81-1186, 64 p.

Chu, Anthony, Monti, Jack, Jr., and Bellitto, A.J., Jr., 1997, Public-supply pumpage in Kings, Queens, and Nassau Counties, New York, 1880-1995: U.S. Geological Survey Open-File Report 97-567, 61 p.

Cohen, Philip, Franke, O.L., and Foxworthy, B.L., 1968, An atlas of Long Island's water resources: New York State Water Resources Commission Bulletin 62, 117 p.

Donaldson, C.D. and Koszalka, E.J., 1983, Potentiometric surface of the Lloyd aquifer, Long Island, in January 1979: U.S. Geological Survey Open-File Report 82-162, 2 sheets, scale 1:250,000.

Doriski, T.P., 1986, Potentiometric-surface altitude of major aquifers on Long Island, New York, in 1983: U.S. Geological Survey Water-Resources Investigations Report 85-4321, 4 pls., scale 1:125,000.

Doriski, T.P., 1987, Potentiometric surface of the watertable, Magothy, and Lloyd aquifers on Long Island, New York, in 1984: U.S. Geological Survey Water-Resources Investigations Report 86-4189, 4 pls., scale 1:125,000.

Franke, O.L., and Cohen, Philip, 1972, Regional rates of ground-water movement on Long Island, New York in Geological Survey Research, 1972: U.S. Geological Survey Professional Paper 800-C, p. C271-277.

Garber, M.S., 1986, Geohydrology of the Lloyd aquifer, Long Island, New York: U.S. Geological Survey Water-Resources Investigations Report 85-4159, 36 p.

Kilburn, Chabot, 1982, Ground-water pumpage in Nassau County, Long Island, New York, 1920-77- Introduction and user's guide to the data compilation: U.S. Geological Survey Open-File Report 81-499, 67 p.

Kimmel, G.E., 1973, Change in potentiometric head in the Lloyd aquifer, Long Island, New York: U.S. Geological Survey Journal of Research, v. 1, no. 3, p. 345-350.

Lusczynski, N.J. and Swarzenski, 1966, Salt-water encroachment in southern Nassau and southeastern Queens Counties, Long Island, New York: U.S. Geological Survey Water-Supply Paper 1613-F, 76 p.

McClymonds, N.E. and Franke, O.L., 1972, Water-transmitting properties of aquifers on Long Island, New York: U.S. Geological Survey Professional Paper 627-E, 24 p.
Misut, P.E., Monti, Jack, Jr., and Voss, C.I., 2002, A ThreeDimensional Finite-Element Model of Seawater intrusion in Western Long Island, New York (abst.), in ASCE Engineering Mechanics Conference, June 2-5, 2002, Columbia University, New York, N.Y., 8 p.

Perlmutter, N.M. and Geraghty, J.J., 1963, Geology and groundwater conditions in southern Nassau and southeastern Queens Counties, Long Island, N.Y.: U.S. Geological Survey WaterSupply Paper 1613-A, 205 p.

Rich, C.A., Prince, K.R., and Spinello, A.G., 1975, Potentiometric surface of the Lloyd aquifer on Long Island, New York, in January 1975: U.S. Geological Survey OpenFile Report, 12 p.

Sirkin, L.A., 1974, Palynology and stratigraphy of Cretaceous strata on Long Island, N.Y. and Block Island, Rhode Island: U.S. Geological Survey Journal of Research, v. 2, no. 4, p. 431-440.

Sirkin, L.A., 1986, Palynology and stratigraphy of Cretaceous and Pleistocene sediments on Long Island, New York-A basis for correlation with New Jersey coastal plain sediments: U.S. Geological Survey Bulletin 1559, 44 p.

Smolensky, D.A., Buxton, H.T., and Shernoff, P.K., 1989, Hydrologic framework of Long Island, New York: U.S. Geological Survey Hydrologic Investigations Atlas HA-709, 3 sheets, scale 1:250,000.

Snavely, D.S. and Williams, James, 1984, Estimated publicwater supply and industrial-commercial ground-water withdrawals and returns in Nassau County, New York, 1973-79: U.S. Geological Survey Water-Resources Investigations Report 84-4246, 16 p.

Soren, Julian, 1971, Ground-water and geohydrologic conditions in Queens County, Long Island, N.Y.: U.S. Geological Survey Water-Supply Paper 2001-A, 39 p.

Soren, Julian, and Simmons, D.L., 1987, Thickness and hydrogeology of aquifers and confining units below the upper glacial aquifer on Long Island, New York: U.S. Geological Survey Water-Resources Investigations Report 86-4175, 3 sheets, scale 1:125,000.

Stumm, Frederick, 2001, Hydrogeology and extent of saltwater intrusion of the Great Neck peninsula, Great Neck, Long Island, New York: U.S. Geological Survey Water-Resources Investigations Report 99-4280, 41 p.

Stumm, Frederick, Lange, A.D., and Candela, J.L., 2002, Hydrogeology and extent of saltwater intrusion on Manhasset Neck, Nassau County, New York: U.S. Geological Survey Water-Resources Investigations Report 00-4193, 42 p.

Stumm, Frederick, Lange, A.D., and Candela, J.L., 2004, Hydrogeology and extent of saltwater intrusion in the Northern Part of the Town of Oyster Bay, Nassau County, New York: U.S. Geological Survey Water-Resources Investigations Report 03-4288, 55 p. 
Suter, Russell, 1937, Engineering report on the water supplies of Long Island: New York State Water Power and Control Commission Bulletin GW-2, 64 p.

Suter, Russell, de Laguna, Wallace, and Perlmutter, N.M., 1949, Mapping of geologic formations and aquifers of Long Island, New York: New York State Water Power and Control Commission Bulletin GW-18, 212 p.
Terracciano, S.A., 1997, Position of the freshwater/saltwater interface in southeastern Queens and southwestern Nassau Counties, Long Island, New York, 1987-88: U.S. Geological Survey Open-File Report 96-456, 17 p.

Veatch, A.C., Slichter, C.S., Bowman, Isaiah, Crosby, W.O., and Horton, R.E., 1906, Underground water resources of Long Island, New York: U.S. Geological Survey Professional Paper 44, 394 p.

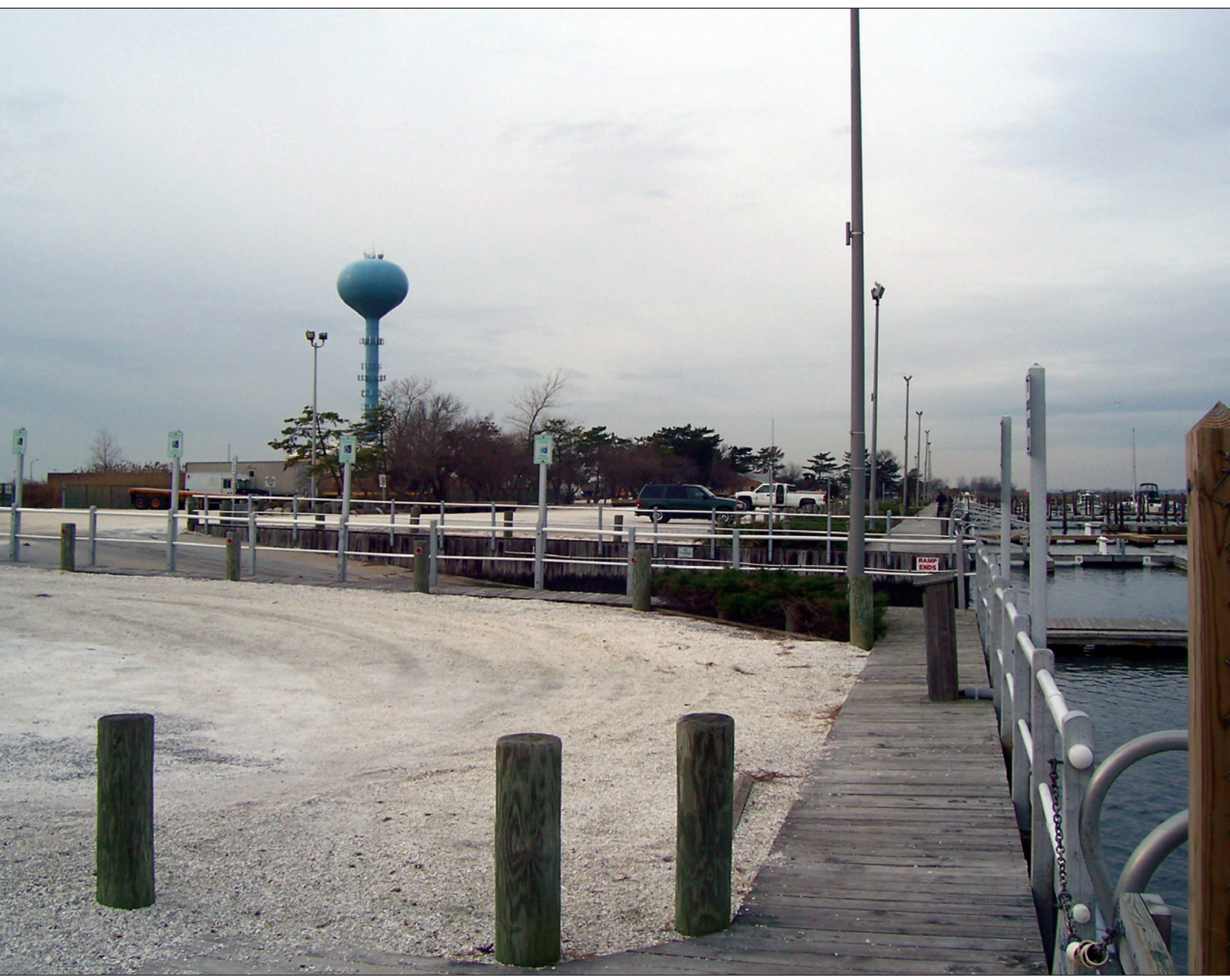

The Lloyd aquifer continues to be an important source of water supply in the shoreline communities. 
Geophysical logs of Lloyd well at west end of Jones Beach, N.Y.

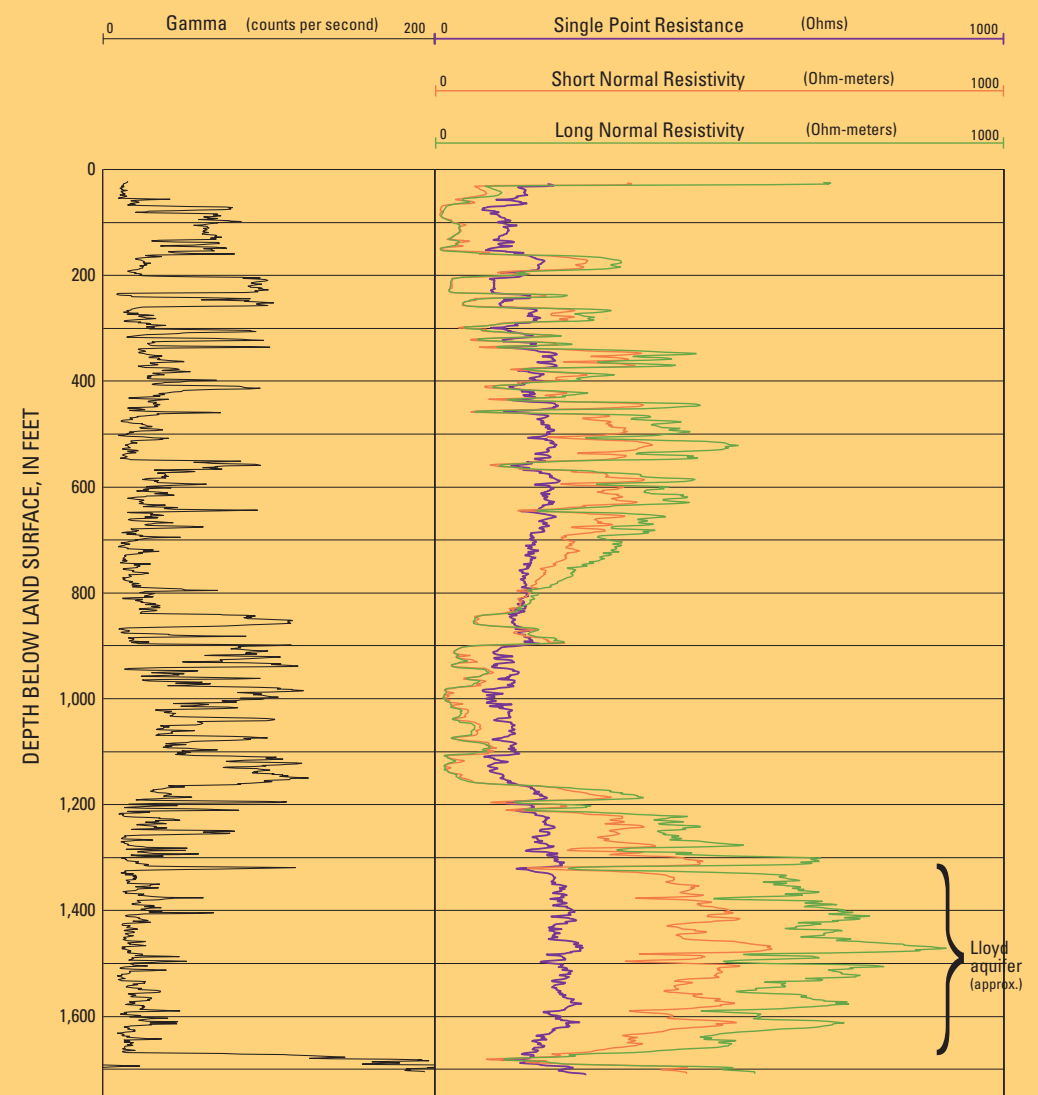

For more information on the USGS--the Federal source for science about the Earth, its natural and living resources, natural hazards, and the environment:

World Wide Web: http://www.usgs.gov Telephone: 1-888-ASK-USGS

For additional information write to: New York Water Science Center U.S. Geological Survey 2045 Route 112, Bldg. 4 Coram, NY 11727

Information requests:

(518) 285-5602

or visit our Web site at:

http://ny.water.usgs.gov

The USGS utilizes geophysical methods to monitor saltwater intrusion.

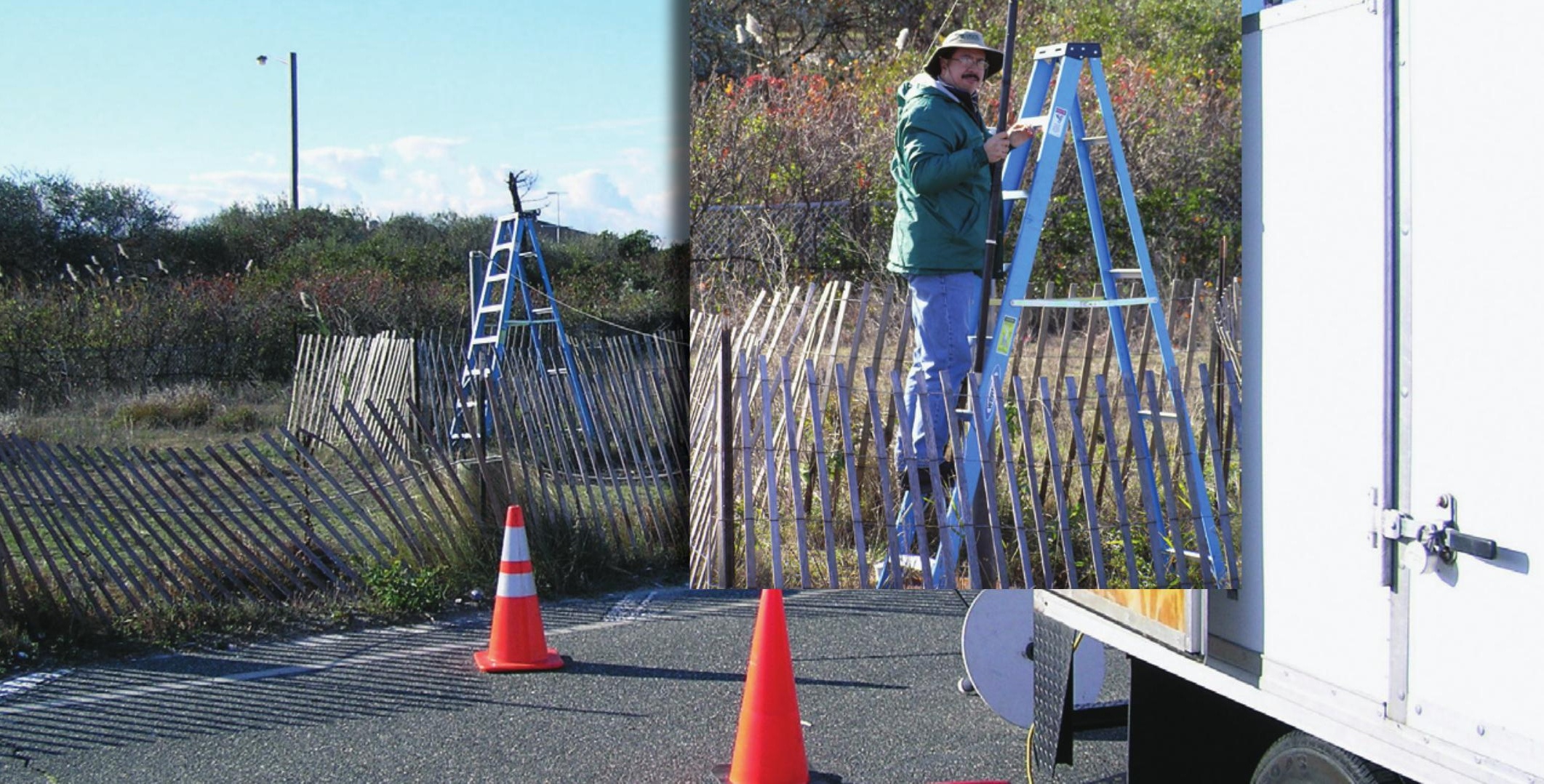

